\title{
Medical tourism: focusing on patients' prior, current, and post experience
}

\author{
Soonae Hwang ${ }^{1}$, DonHee Lee ${ }^{2^{*}}$ (D) and Chang-Yuil Kang ${ }^{3}$
}

\author{
* Correspondence: \\ dhlee04@inha.ac.kr \\ ${ }^{2}$ College of Business Administration, \\ Inha University, Incheon, South \\ Korea \\ Full list of author information is \\ available at the end of the article
}

\begin{abstract}
This study empirically examines the effects of medical tourists' experience of the decision-making process through a patient's prior, actual, and post experience after having received the medical services. The research model and associated hypotheses were tested using a structural equation modeling based on data collected from 188 medical tourists who received care in Busan, South Korea. The findings of the study indicate that patients' experience in medical tourism pre-search (reputation, searching information, and communication) has a partially positive effect on their experience (costs, care quality, and supporting system and/or information) and patients' current experience during the medical tour process has a positive effect on post-experience (relationship building, recommendation, and feedback). The results of this study provide new insights about how key players (e.g., hospitals, medical travel agencies, hotels, and the medical tourists themselves) in medical tourism can effectively help managers identify medical tourists' needs based on the decisionmaking process of prior, current, and post-experience of medical tourists.
\end{abstract}

Keywords: Medical tourism, Prior-current-post experience, Medical tourists, Decisionmaking process, South Korea

\section{Background}

Medical tourism has emerged as a result of consumers being exposed to a wider range of choices of medical services and exponential growth in global healthcare market [1]. A combination of the terms "medical" and "tourism" [1], its main target is patients who visit other regions or countries for medical treatment. Therefore, the medical tourism industry is geared toward significant efforts to meet people's desire for a better wellness with quality medical treatment [2, 3]. According to the Allied Market Research [4], the net worth of the medical tourism market worldwide is estimated at $\$ 61.172$ billion as of 2016 and is expected to increase to $\$ 165.3$ billion by 2023 .

The global growth of the medical tourism industry is most prominent in Asia, with Singapore, Thailand, South Korea, and India being well known as medical tourism countries. In a report "Estimates of the South Korea Medical Tourism Market and Expenditure to 2020," Orbis Research [5] presented that highly skilled professionals, advanced medical devices, and well-established infrastructures are the factors that contribute to the rapid growth of medical tourism in South Korea.

Customers opting for medical tourism visit local hospitals in other countries and/or regions, where they use this opportunity to relax and enjoy cultural activities in

(c) The Author(s). 2018 Open Access This article is distributed under the terms of the Creative Commons Attribution 4.0 International License (http://creativecommons.org/licenses/by/4.0/), which permits unrestricted use, distribution, and reproduction in any medium, provided you give appropriate credit to the original author(s) and the source, provide a link to the Creative Commons license, and indicate if changes were made. 
addition to seeking medical treatment, maintenance, and recovery. Increased promotions of a wide range of one-stop medical services and advancements in medical technology have made traveling for treatment a rather convenient and attractive prospect for medical tourists $[2,5,6]$. Information retrieval for overseas medical care is one of the components in the decision-making process for medical tourism [6]. The quality of medical services and expertise of institutions in other countries may also be important factors since they influence patients' access to medical information [1]. Therefore, the industry should extend greater efforts in this area to attract more patients.

Medical services create value-generating activities through an effective interaction of human resources (service providers and recipients), processes, technologies, and/or material resources. Interaction activities reflect consumer needs, and these activities can lead to improvements in medical services delivery [1, 7-9]. Therefore, the interaction at each service encounter is very important. Also, patient experience upon receiving medical services will influence future decision-making of patients, as has been shown in previous studies on the importance of experience [10,11]. The customer experience consists of multiple independent service encounters throughout the exchange process [11]. As a matter of fact, customer experience is becoming significantly more important as itself has become the target customer, and ideas proposed by customers can generate a value proposition, which can lead to a newer and improved revenue model $[12,13]$.

Patients' evaluation of a hospital's medical services is based on his/her own experience or others' recommendation influences not just the local population but also potential customers from overseas [14]. Ofir and Simonson [15] suggested that customer brand perceptions through purchase evaluations of experience have a significant effect on the customer's experience. Thus, to obtain favorable customer reviews, healthcare organizations provide patient-oriented medical services mainly by interacting with their patients at each service encounter. This is why it is imperative to build processes that focus on delivering better, customer-oriented medical services for positive customer experience.

A process is a set of activities for creating value for the customer through inputprocess-output, so the process can vary depending on the requirements of the customer. Medical services are provided only when patients and medical staff meet in a service encounter. Therefore, various processes can be set up depending on the type and severity of the disease and the patient's health condition. A more comprehensive approach may be needed as patient outcomes are a result of not just one process but a combination of processes before, during, and after the overall process of medical service. While customers search healthcare providers before their visit, their revisit intention is dependent on the institutions' care processes and outcomes $[9,11]$. However, due to the nature of medical care, patients may not be able to easily switch medical institutions, their experience will nevertheless have a direct or indirect bearing on other prospective patients' decisions [9].

While previous studies already have and continue to examine the importance of experience, they have focused largely on customer experience from arrival to departure rather than comprehensive processes $[1,3,6,10,13]$. As such, it is necessary to take a more holistic approach to studying customer experience through before, during, and after service provision. This study focuses on the decision-making process in customer experience. More specifically, it aims to examine the patient's pre-experience of 
researching medical services abroad, the actual experience during their trip, and the post-experience after having received the medical services.

This study thus attempts to answer the following two basic research questions: (1) Does the experience of those who pre-searched for medical tourism impact their current experience in medical tourism? (2) Does patients' experience during medical tour impact post-experience? A research model is proposed to answer these questions. The result of the study is expected to contribute to both theory and practice of medical tourism regarding customer experience through the decision-making process of prior, current, and post medical tours.

The rest of the paper is organized as follows: Section "Review of relevant literature" reviews relevant literature and proposes conceptual development, section "Research methodology" develops the hypotheses; section "Results" presents the research methodology is presented, section "Discussion and conclusions" reports the results of analysis and concludes the study by articulating the results, implications, and limitations of the study, and future research needs.

\section{Review of relevant literature Medical tourism}

The definition of medical tourism varies among researchers depending on the choice of place and location (domestic or foreign) of medical tourism, the method and procedure applied, application, and/or processes. Generally, it is referred to as tourism activities related to medical treatments or activities to improve tourists' well-being. The Medical Tourism Association [16] defines medical tourism as "where people who live in one country travel to another country to receive medical, dental and surgical care while at the same time receiving equal to or greater care than they would have in their own country, and are traveling for medical care because of affordability, better access to care or a higher level of quality of care." Wongkit and Mckercher [17] defined medical tourism as "the travel of people to specific destinations to seek medical help that forms the primary purpose of their trip."

The Tourism Research and Marketing [18] presented treatment of illnesses, enhancement/cosmetic surgery, wellness, and fertility-related treatments as types of medical tourism. Lunt et al. [19] described the range of treatments in the medical tourism sector, focusing mainly on the common factors suggested in many previous studies: "cosmetic surgery (breast, face, liposuction); dentistry (cosmetic and reconstruction); cardiology/cardiac surgery (bypass, valve replacement); orthopedic surgery (hip replacement, resurfacing, knee replacement, joint surgery); bariatric surgery (gastric bypass, gastric banding); fertility/reproductive system (IVF, gender reassignment); organ, cell and tissue transplantation (organ transplantation; stem cell); eye surgery and diagnostics and check-ups."

The quality of medical services is one of the factors that potential customers consider most important [18]. This implies that the quality of medical service and its costs are the most important influencers in their decision on the destination for their medical tourism [20]. Lunt et al. [19] emphasized that customers should be informed of the potential benefits of medical tourism regarding credible evidence of quality care and safety of their stay. In particular, when compared to other service industries, where word-of-mouth plays a big role, the medical industry is relatively slow in adopting a 
business model focused on customer satisfaction. With the right focus on quality and outcomes of the medical service processes, including customer interaction with service providers, healthcare organizations should try to improve patient satisfaction. This will have a positive effect on attracting potential future customers, thus promoting medical tourism [21].

Ehrbeck et al. [22] suggested five factors that promote medical tourism through a survey of 49,980 patients: most advanced technology (40\%), better-quality care for medically necessary procedures (32\%), quicker access to medically necessary procedures (15\%), lower-cost care for medically necessary procedures (9\%), and lower-cost care for discretionary procedures (4\%). Crook et al. [23] presented the following as the most frequently discussed topics on patient experience: (1) decision-making (e.g., push-and-pull factors that shape patients' decisions); (2) motivations (e.g., procedure, costs, and travel-based factors motivating patients to seek care abroad); (3) risks (e.g., health and travel risks); and (4) first-hand accounts (e.g., patients' experiential accounts of having gone abroad for medical care). Thus, we consider combining the factors suggested by Ehrbeck et al. [22] and Crook et al. [23] to devise new strategic measures for medical tourism.

Few potential medical tourists are aware of what products or services are available through medical tourism. Some may have misconceptions and fear of various situations, including anxiety about traveling possible dangers, culture shock, and language barriers. In addition, it is very difficult for medical tourists to search for healthcare providers with accurate information in different countries individually for the treatment of diseases and for finding relevant wellness/sightseeing information.

In general, unlike making a decision to buy commercial products or services, the decision-making process for medical tourism is very complicated as it also involves emotional aspects that lead to multidimensional behaviors [24]. A variety of factors can affect decision-making of medical tourism because it influences not only physical (medical services) but also mental (tour) health conditions during and after activities [22, 23].

Medical tourism advertisements tend to focus too much on treatment results and outcomes rather than quality improvements and safety [25]. When customers base their decisions on over- or underestimated advertisements, there tends to be a gap between the expected and actual outcomes. The increasing media interest in medical tourism has made it popular on a global platform, and today, we can obtain information on medical tourism destinations through various channels, including newspapers, magazines, radio, and television programs [25]. Online marketing efforts via web help publicize medical tourism [26, 27]. Ormond and Sothern [28] analyzed five medical tourism guide books and found that a common factor among the books was to encourage potential customers to tour rather than introduce destinations and international choices for medical services. Thus, a sufficient preliminary investigation in advance is necessary for medical tourism. Customers can make the final decision through proper search of a variety of information and comparing them with services offered by providers in other regions or countries. It is suggested that a synergistic approach is more effective when it is done in a comprehensive way than in a piecemeal information survey [29].

Medical services comprise those put into the service (patients and medical staff), organization (service providers, service or products), treatment procedures, and outcomes [30]. As each process generates activities for medical treatment through interaction with patients, Lee [12] divided the process of value creation into preprocessing, 
responding process, and resulting processes. The preprocessing refers to a set of preparative activities in advance of care services, the responding process as the one to respond to interactions during treatment, and the resulting processes as related to the prevention and outcome of disease. Thus, sufficient information should be provided to customers about the entire process rather than at the time of experiencing each process. Once customers achieve their goal of getting the desired outcome, they will go back home and may come back for further treatments for better quality of life or wellness (repurchase or any positive activities) or the other way around (negative activities). Customers make their decisions based on what they searched before selecting the destination. It means that they would first experience medical tourism through Googling; feedback from colleagues, friends, or family; or direct communication with the hospital.

Medical tourism is a major decision problem for the patient; it is much more involved than deciding to visit a local healthcare provider. The customer's experience of medical tourism is the main factor that influences his/her satisfaction which in turn would influence revisit intention. Thus, it should be a major strategic priority for medical tourism hospitals and their administrators to develop a system that can provide positive experience to customers. Many tourism hospitals have a one-stop service system for their customers that may include such services as government documents (visa service), transportation (air flight reservations, airport pickup, shuttle service, etc.), language help, local hotel reservations, insurance processing, financial arrangements, local tour attractions, and the like. For example, Bumrungrad Hospital in Bangkok, Thailand, which is ranked ninth in the top ten hospitals in the world, provides a very efficient one-stop service to foreign customers (VIP airport transfers, interpreters, concierge services, embassy assistance, international insurance arrangements, and medical coordinators, see http://www.bangkok.com/hospitals-private-hospitals.htm).

\section{Experience of customers}

Since customers' overall satisfaction may be subjective, recent studies have emphasized the importance of customer experience and strategic approaches to improve the quality of medical services [12].

Merlino and Raman ([31], p.113) suggested that patient experience is a strategic priority and provided a broad definition: "The patient experience was everyone and everything people encountered from the time they decided to go to the clinic until they were discharged." Meyer and Schwager ([7], p.118) defined customer experience as "the internal and subjective response customers have to any direct or indirect contact with a company", and De Keyser et al. ([8], p.23) also suggested customer experience as "comprised of the cognitive, emotional, physical, sensorial, spiritual, and social elements." These definitions imply that patient experience includes cognitive activities (e.g., checking reputation and searching other relevant information) before going to the hospital to the post-discharge behaviors (e.g., recommendation and feedback) with patient's own emotional and subjective judgments.

In particular, medical tourism needs to be investigated thoroughly prior to the travel, because it focuses not only on information of medical institutions but also on the region or country where they will receive treatment. New advanced technologies can earn positive reviews from consumers and succeed only if they are unique in terms of their 
functions, convenience, and attractiveness. The positive images created from this could generate favorable responses from customers as they make comparisons based on actual use or indirect experience. In other words, customers' direct or indirect experiences can affect their future repurchase intention.

The direct and indirect experience gained during the preliminary investigation will affect the process of receiving the actual medical service [12]. Further, if the gap between expectation and reality increases, there will be a decline in satisfaction. It will also affect revisit intention. In addition, since the medical services provided to patients with various diagnoses and administration services that are multidimensional, it is difficult to directly measure patient experience. As customer satisfaction might be improved based on their experience, customer satisfaction should also be included in the behavior of the customers' preparation before arriving at the destination [12].

Verhoef et al. [11] suggested customer experience as "the total experience, including the search, purchase, consumption, and after-sale phases of the experience." The prior experience occurs before purchase and consumption, and the purchase and consumption represents current experience, and after-sale/consumption experience represents post-experience. Therefore, in this study, the patient experience in medical tourism can be divided into prior experience for deciding on medical tourism, current experience during the treatment and/or medical tour, and post-experience after treatment and/or tour.

The prior experience includes the direct or indirect experience of customers during various activities before actually experiencing the main service, medical tourism. Patients can search various information, such as reputation, specialized treatment, and interesting tour destinations, directly or indirectly before choosing a hospital for the best possible treatment and service. Since the customer's decision-making is based on a thorough prior investigation [7], sufficient communication with the customer is necessary. Patients can of course directly consult with the medical staff or service personnel of a hospital via video chatting (e. g., Skype or FaceTime) or telephone. In this study, the prior experience was categorized into checking reputation, searching information, and communication.

Through prior experience, customers make their final decisions for medical tourism, receive actual medical services, and have various other experiences. They are involved in direct communication with service providers, direct engagement in the service provision processes, and witnessing a gap between what they expected and the service actually received. Therefore, the current experience in this study refers to customer experience while engaging in various activities at the hospital, including interaction with service providers or other customers, use of information and comminutions technology (ICT), and enjoying the service environment. The current experience was categorized into checking costs, care quality, and supporting system and other relevant information.

Customers come to evaluate their own experience based on expectations, current experience, and other activities. Their experiences may generate either positive or negative impact on others. From the customers' perspective, the post-experience influences the intention to repurchase or has a positive word-of-mouth. Service providers, on the other hand, may search for new ways to retain customers and improve their satisfaction through their post-experience (i.e., surveys or social networking). Sridhar and Srinivasan [32] suggested that the reviews customers read in advance actually influence purchase intention or encourage them to share their own feedback online after purchase 
and encouraged organizations to work hard to create positive customer experiences for "leaving good memories." Thus, the post-experience of customers extends the processes continuously as it affects their prior, current, and post experience [10]. Consequently, the post-experience in this study refers to experiences that will influence patients' decision on what to do after service provision. The post-experience includes relationship building, recommendation, and feedback.

As discussed earlier, decision-making for medical tourism can be determined with a variety of patient experiences. Thus, this study examines the effects of experience of medical tourists on the decision-making process. The proposed research model is shown in Fig. 1.

\section{Methods}

\section{Hypotheses development}

\section{Prior and current experience}

As it is difficult to set clear standards on hospital selection, which is the most critical factor of medical tourism, and vacation spots, most patients make decisions based on their own experience, information technology, and prior patients' feedback [10]. In recent years, with the advent of smart devices and ICT, both patients and providers can access the information they want directly or indirectly and can easily make their own decisions. The decision process is also influenced by the changing business environment as well as purchase patterns of patients [33, 34].

Hospital reputation is an important factor in patients' decision-making [18]. Ferguson et al. [35] argued that medical service providers can enforce patient loyalty and maximize word-of-mouth effect efficiently. Based on a study of hospitals in Taiwan, Cheng et al. [36] suggested that recommendations made by patients form an important factor in attracting patients for medical tourism. Therefore, recommendations from family, friends, or colleagues become a critical factor in hospital selection [36].

Prior experience begins with customers searching for, reviewing information, or asking someone about key services. Many customers seek information from online reviews, asking medical staff questions, or going through onboarding processes [10]. For instance, in prior experience, a customer may communicate with physicians by filling out documents before making an appointment, review information about hotels in the destination area, or use a Twitter before the trip. As mentioned above, current experience includes experiences during service delivery through meeting physicians, using

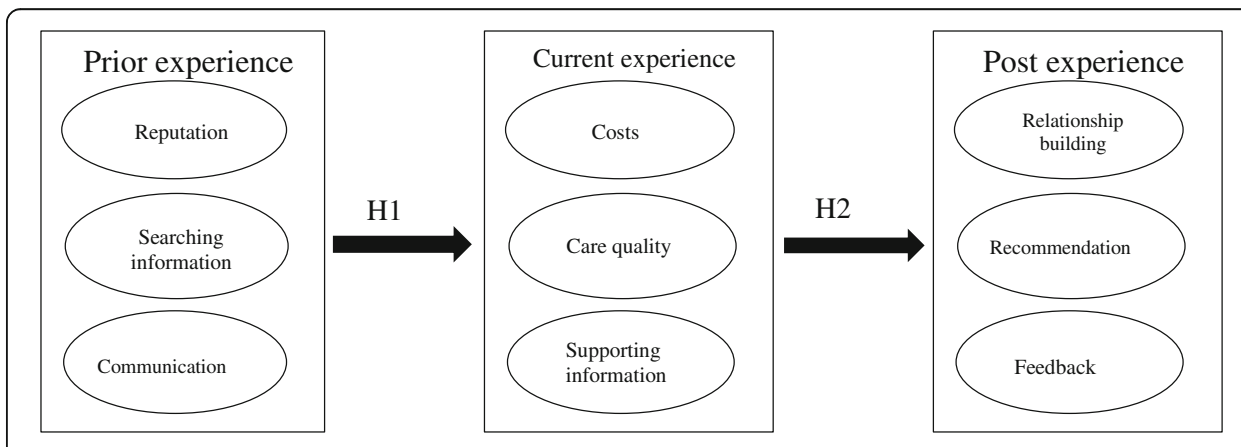

Fig. 1 Proposed research model 
hospital facilities, staying at a hotel, or visiting tourist attractions in the selected region $[10,37,38]$.

Patients' positive or negative perceptions are based on the quality of service they received at the hospital. They come to build these positive or negative images after comparing their expectations with what they actually experienced at the selected hospital at the time of getting the medical treatment. Since medical services are delivered through interaction between patients and physicians, patients show mixed responses depending on the kind of services they received at the hospital. Such variations in response result in from the gap between what they expected based on prior experience and their evaluation of the actual services, which will ultimately affect their future decision [12]. Therefore, prior experience should be considered to have an effect on current experience. The following hypothesis is proposed.

Hypothesis 1: Patients' experience in medical tourism pre-search has a positive effect on their current experience.

H1-1: Reputation gained through the prior experience of a hospital has a positive effect on costs related with medical tourism.

H1-2: Reputation gained through the prior experience has a positive effect on care quality.

H1-3: Reputation gained through the prior experience has a positive effect on supporting system and/or information.

H1-4: Searching information gained through the prior experience has a positive effect on costs related with medical tourism.

H1-5: Searching information gained through the prior experience has a positive effect on care quality.

H1-6: Searching information gained through the prior experience has a positive effect on supporting system and/or information.

H1-7: Communication gained through the prior experience has a positive effect on costs related with medical tourism.

H1-8: Communication gained through the prior experience has a positive effect on care quality.

H1-9: Communication gained through the prior experience has a positive effect on supporting system and/or information.

\section{Current and post experience}

When a customer chooses a service through the evaluation of available information or word-of-mouth and dissatisfied with the service received, he/she may switch to another service provider. Even though patients themselves may not be able to change hospitals easily, owing to the nature of the medical service, their dissatisfaction can have a direct or indirect effect on others. For instance, patient "A" was discharged from hospital "B" after undergoing a surgery. Even if patient $\mathrm{A}$ is not satisfied with hospital $\mathrm{B}$, he/she may be compelled to visit hospital B for a follow-up service. However, patient A may discourage potential patients from visiting hospital B through negative word-of-mouth based on his/her own experience. Therefore, to provide medical services with positive effects on other patients, hospital should recognize that the patient has selected a 
particular hospital after carefully considering and searching hospitals directly or indirectly. Especially, patients choose hospitals for medical tourism abroad because they are not satisfied with their current care providers. Consequently, provision of diverse and accurate information is necessary for medical tourism $[2,3]$.

Previous studies suggest that patients make decision based on their cognitions about something $\rightarrow$ evaluation and emotions $\rightarrow$ acting for outcomes [10]. de al Hoz-Correa et al. ([2], p.208) pointed out that the key factor to be considered by the medical tourism industry in the future should be the "consequences of commodification in healthcare pressures for privatization of health in departure and host countries." This means that hospitals should take measures for more effective communication and provide adequate explanations during the medical treatment and try to relieve patient dissatisfaction by offering follow-up options. In addition, hospitals should offer patients guidance regarding medical insurance before treatment so as to prevent any conflict after the treatment. Therefore, medical tourism hospitals should provide all the pertinent information to potential patients so that they can make intelligent decisions in selecting the best hospital for their unique needs with quality care and positive experience. By doing so, they can create positive outcomes. Such activities could encourage patients to have positive experiences, share their satisfaction with others, and make more visits in the future.

Revisit intention is based on patients' overall experience of the service, which will influence their future decisions. Polluste et al. [39] stated that revisit intention can be positively influenced by respecting and reflecting patient demands and opinions, and striving to improve patient experience through direct interaction with patients. Therefore, the current experience during treatment or at a tourism spot influences post-experience and encourages multiple visits and positive word-of-mouth effects [40]. Thus, the following hypothesis is suggested.

Hypothesis 2: Patients' current experience during the medical tour process has a positive effect on post-experience.

H2-1: Costs related with medical tourism gained through the patients' current experience has a positive effect on relationship building.

H2-2: Costs related with medical tourism gained through the patients' current experience has a positive effect on recommendation.

H2-3: Costs related with medical tourism gained through the current experience has a positive effect on feedback.

$\mathrm{H} 2-4$ : Care quality gained through the current experience has a positive effect on relationship building.

H2-5: Care quality gained through the current experience has a positive effect on recommendation.

H2-6: Care quality gained through the current experience has a positive effect on feedback.

H2-7: Supporting system and/or information gained through the current experience has a positive effect on relationship building.

H2-8: Supporting system and/or information gained through the current experience has a positive effect on recommendation.

H2-9: Supporting system and/or information gained through the current experience has a positive effect on feedback. 


\section{Data collection}

Data was collected from medical tourists who were in stable enough conditions for this survey and were willing to participate. Hospitals in this survey participated on a voluntary basis. The main reason for using this sampling approach was that South Korea represents a major country with highly skilled professionals, advanced medical devices, and well-established infrastructures for medical tourism [5]. The target population of this study was the international medical tourists traveling to seeking medical services in selected hospitals in Busan, South Korea during April 2018-May 2018. The researcher was assisted by the hospitals' administration team, and the hospital staff assisted in finding medical tourists at the time of research and provided the responses to the researcher.

A survey questionnaire was developed using the double translation protocol [41]. The questionnaire was developed in English first and then translated into Korean by two bilingual operations management faculty in Korea. The Korean version was translated back into English by two American operations management experts who are also bilingual. The two English versions of the questionnaire had no significant difference.

The initial questionnaire was tested in a pilot survey involving 30 participating medical tourists in a Korean hospital. The reasons for this pilot test were to ensure the participating medical tourists clearly and fully understood the questionnaire items. After the pilot study, the number of measurement items of each variable was reduced as some items suggested by managers were difficult to measure precisely. The final questionnaire is shown in Table 1 and provides the measurement items for prior, current, and post experience of medical tourists.

To collect data, we were helped by the medical staff and medical consultants since patients were from various countries (Japan, China, Russia, Mongolia, and others) and the participating hospitals in this study were all medical tourism hospitals. Out of 500 questionnaires that were distributed to medical tourists, subsequently, 188 (37.6\%) responses returned useable questionnaires. The respondents' demographics and their hospitals' characteristics are summarized in Table 2.

As shown in Table 2, majority respondents' nationality is Japanese (53.7\%), Chinese (16.5\%), and Russian (10.6\%),

Of respondents, $92 \%$ traveled to Korea for the first time, and another $18 \%$ were here for the second time. Majority of the respondents are going to stay more than 15 days to less than 22 days in Korean (70.4\%). A total of $80.9 \%$ of respondents' primary purpose of this visit is to receive medical service, while not medical service was $19.1 \%$. About $30.3 \%$ of medical tourist wanted to cosmetic/plastic/reconstructive surgery, and 26.1\% wanted to dental treatment during their trip in Korea. Almost (96.3\%) of respondents made their decision based on word-of-mouth information and $3.7 \%$ on their experiences. More than half $(53.7 \%)$ of the respondents chose medical tourism because of medical costs, and then quality of care service (24.5\%).

\section{Variables of the model}

The questionnaire utilized 5-point Likert scales to measure the constructs. The data was analyzed by SPSS 23.0 and AMOS 23.0 programs. Structural equation modeling (SEM) was chosen because it provides all the tools necessary to test the hypotheses. 
Table 1 Measurement items

\begin{tabular}{|c|c|c|c|}
\hline Variables & & Measurement items & References \\
\hline \multirow[t]{12}{*}{ Prior experience } & \multirow[t]{3}{*}{ Reputation (RE) } & $\begin{array}{l}\text { - RE1: The quality of healthcare in South Korea } \\
\text { is well known }\end{array}$ & \multirow[t]{3}{*}{ Al-Maaitah [51] } \\
\hline & & $\begin{array}{l}\text { - RE2: Everybody knows that the quality of care } \\
\text { here is good }\end{array}$ & \\
\hline & & $\begin{array}{l}\text { - RE3: South Korea has a good global reputation } \\
\text { for healthcare }\end{array}$ & \\
\hline & \multirow[t]{5}{*}{ Searching information (SI) } & $\begin{array}{l}\text { - SI1: I searched for information on medical } \\
\text { tourism through various media }\end{array}$ & \multirow{5}{*}{$\begin{array}{l}\text { Al-Maaitah [51] } \\
\text { Voorhees } \\
\text { et al. [10] }\end{array}$} \\
\hline & & $\begin{array}{l}\text { - SI2: I searched for information on medical } \\
\text { tourism through a private medical } \\
\text { tourism agency }\end{array}$ & \\
\hline & & $\begin{array}{l}\text { - SI3: I asked for recommendations from friends } \\
\text { and relatives }\end{array}$ & \\
\hline & & - SI4: I looked at guide books and/or brochures & \\
\hline & & $\begin{array}{l}\text { - SI5: I acquired information from South Korean } \\
\text { hospital representative offices }\end{array}$ & \\
\hline & \multirow[t]{4}{*}{ Communication (CO) } & $\begin{array}{l}\text { - CO1: The physician had good communication } \\
\text { skills }\end{array}$ & \multirow[t]{4}{*}{$\begin{array}{l}\text { Voorhees } \\
\text { et al. [10] }\end{array}$} \\
\hline & & $\begin{array}{l}\text { - CO2: I received quick responses to the } \\
\text { questions I sent via email or posted } \\
\text { on social networking platforms }\end{array}$ & \\
\hline & & $\begin{array}{l}\text { - } \mathrm{CO} 3 \text { : I communicated well with the } \\
\text { person-in-charge at the travel agency }\end{array}$ & \\
\hline & & $\begin{array}{l}\cdot \text { CO4: The online material was easy to } \\
\text { understand }\end{array}$ & \\
\hline \multirow[t]{12}{*}{ Current experience } & \multirow[t]{4}{*}{ Costs (CT) } & $\begin{array}{l}\text { - CT1: The price of both domestic and distant } \\
\text { healthcare services were reasonable }\end{array}$ & \multirow[t]{4}{*}{ Al-Maaitah [51] } \\
\hline & & $\begin{array}{l}\text { - } C T 2 \text { : I received quality medical treatment } \\
\text { at a reasonable price }\end{array}$ & \\
\hline & & $\begin{array}{l}\text { - CT3: This medical treatment was good } \\
\text { value for money }\end{array}$ & \\
\hline & & $\begin{array}{l}\text { - CT4: Overall, the medical tourism costs } \\
\text { were quite a reasonable }\end{array}$ & \\
\hline & \multirow[t]{5}{*}{ Care quality (CQ) } & $\begin{array}{l}\text { - CQ1: The physicians paid enough attention } \\
\text { to my concerns in deciding on a } \\
\text { medical procedure }\end{array}$ & \multirow[t]{5}{*}{ Saiprasert [57] } \\
\hline & & $\begin{array}{l}\text { - CQ2: The physicians adequately explained } \\
\text { my condition, examination results, } \\
\text { and medical processes }\end{array}$ & \\
\hline & & $\begin{array}{l}\text { - CQ3: Setting up the medical procedure } \\
\text { appointment was simple and easy }\end{array}$ & \\
\hline & & $\begin{array}{l}\text { - CQ4: The waiting time for an examination was } \\
\text { short at this hospital }\end{array}$ & \\
\hline & & $\begin{array}{l}\text { - CQ5: Overall, I was satisfied with the medical } \\
\text { service }\end{array}$ & \\
\hline & \multirow[t]{3}{*}{$\begin{array}{l}\text { Supporting system } \\
\text { and/or information (SU) }\end{array}$} & $\begin{array}{l}\text { - SU1: I received full guidance while being } \\
\text { treated in this hospital }\end{array}$ & \multirow[t]{3}{*}{ Al-Maaitah [51] } \\
\hline & & $\begin{array}{l}\text { - SU2: Advanced ICT systems supported medical } \\
\text { services in this hospital }\end{array}$ & \\
\hline & & $\begin{array}{l}\text { - SU3: It was easy to use ICT systems in this } \\
\text { hospital }\end{array}$ & \\
\hline \multirow[t]{3}{*}{ Post-experience } & \multirow[t]{3}{*}{ Relationship building (RB) } & $\begin{array}{l}\text {-RB1: I will continue my relationship with } \\
\text { this hospital }\end{array}$ & \multirow[t]{3}{*}{$\begin{array}{l}\text { Voorhees } \\
\text { et al. [10] }\end{array}$} \\
\hline & & $\begin{array}{l}\text { - RB2: Patient reviews influenced the relationship } \\
\text { between me and the hospital }\end{array}$ & \\
\hline & & $\begin{array}{l}\text { - RB3: A standardized process is needed to foster } \\
\text { better relationships }\end{array}$ & \\
\hline
\end{tabular}


Table 1 Measurement items (Continued)

\begin{tabular}{|c|c|c|c|}
\hline \multirow{2}{*}{\multicolumn{2}{|c|}{ Variables }} & \multirow{2}{*}{$\begin{array}{l}\text { Measurement items } \\
\text { - RB4: I will be more likely to maintain my } \\
\text { relationship with the hospital if I keep } \\
\text { receiving updated medical information } \\
\text { from the institution online }\end{array}$} & \multirow[t]{2}{*}{ References } \\
\hline & & & \\
\hline & \multirow[t]{3}{*}{ Recommendation (RC) } & $\begin{array}{l}\text { - RC1: I would consider South Korea as my } \\
\text { first choice for medical tourism }\end{array}$ & Al-Maaitah [57] \\
\hline & & $\begin{array}{l}\text { - RC2: I would be willing to continue further } \\
\text { medical treatment at this hospital in } \\
\text { South Korea }\end{array}$ & \\
\hline & & $\begin{array}{l}\text { - RC3: I would be willing to recommend this } \\
\text { medical treatment in South Korea to } \\
\text { my relatives and close friends }\end{array}$ & \\
\hline & \multirow[t]{3}{*}{ Feedback (FB) } & $\begin{array}{l}\text { - FB1: It is important for the hospital to voluntarily } \\
\text { provide feedback for potential customers }\end{array}$ & \multirow[t]{3}{*}{ Crooks et al. [23] } \\
\hline & & $\begin{array}{l}\text { - FB2: It is necessary to write a report on } \\
\text { how satisfied the patients were with } \\
\text { the treatment }\end{array}$ & \\
\hline & & $\begin{array}{l}\text { - FB3: Hospitals should respond to the negative } \\
\text { perceptions of patients }\end{array}$ & \\
\hline
\end{tabular}

Reliability was tested based on Cronbach's alpha value (Table 3). In the reliability test, Cronbach's alpha value of relationship building on post-experience was highest (.945), and supporting system and/or information on current experience was lowest (.736). All of the coefficients of reliability measures for the constructs exceeded the threshold value of .70 for exploratory constructs in basic research [42].

For validity test, the principal component analysis (PCA; minimizes the sum of squared perpendicular distance to the component axis) and the confirmatory factor analysis (CFA) were used to identify the most meaningful basis and to examine similarities and differences of the data based on Brown's [43] recommendation. Eigen values and percent of variance explained for each construct are shown in Table 3. The cumulative percentages of explained variance were exceeded $70 \%$ for the each constructs on statistics of PCA. The loading values of each factor ranged from .566 (CQ5) to 957 (RB4) as shown in Table 3.

The results of CFA can provide evidence of the convergent and discriminant validity of theoretical constructs [44]. This measurement model consisted of nine components of reputation, searching information, communication, costs, care quality, supporting system and/or information, relationship building, recommendation, and feedback. The standardized factor loadings and $t$ values for measurement variables, results of CFAs to test the measurement model for all construct using the AMOS 23 program, are presented in Table 3. The values of standardized regression weight and all variables proposed by the study exceeded .5 and were statistically significant at the .05 level.

The results of goodness of fit test for the measurement model are summarized and shown in Table 4. Compared to the recommended values for the goodness of fit tests, the values of CFI, RMR, RMSEA, TLI, and $\chi^{2}$ /d.f. were satisfactory, while the value of GFI was not. Deepen [44] suggested that GFI is desired to be over 0.9; however, "this must not automatically require the model to be rejected." In our model, the majority of fit indices showed good acceptance measures and only GFI and AGFI were below the required thresholds. 
Table 2 Respondent' characteristics

Respondents' characteristics
Gender
Male
Female
Age
More than 18 to more than 65
Nationality
Japan
China
Russia
Mongolia
Thailand
Malaysia
Canada
United States
Singapore
Vietnam

Frequency

62

126

188

$100.0 \%$

101

$53.7 \%$

31

$16.5 \%$

$10.6 \%$

17

$9.0 \%$

17

7

5

3

2

1

1

Number of visits to Korea for medical tourism

First time

$92.0 \%$

2 times

Influential factor for medical tourism destination

Recommendation

$96.3 \%$

Own experience

Primary purpose of this visit

Medical service

Not medical service:

Business/work (10.1\%), Vacation (5.9\%),

Visit friend and relatives (1.6\%), Missing (82.4\%)

Type of medical service

Cosmetic/plastic/reconstructive surgery

$30.3 \%$

Dental treatment

Sight treatment

Disease diagnosis

Comprehensive medical checkup

$13.3 \%$

25

$4.8 \%$

Follow-up to a previous

$12.2 \%$

Sources of information for medical trip

Website of hospital in South Korea

Reading the testimonies of other patients

Word-of- mouth from friends or relatives

Advice of doctor/physician in your country

Online medical communities

Reasons to choose medical tourism

Medical costs

Quality of care service

Reputation 
Table 2 Respondent' characteristics (Continued)

\begin{tabular}{lll}
\hline Respondents' characteristics & Frequency & Percent (\%) \\
\hline Waiting & 7 & $3.7 \%$ \\
Length of stay medical treatment in South Korea & 16 & $8.5 \%$ \\
Less than 7 days & 15 & $8.0 \%$ \\
More than 7 days to less than 15 days & 133 & $70.4 \%$ \\
More than 15 days to less than 22 days & 24 & $12.8 \%$ \\
More than 21 days & & \\
Perception of care costs in South Korea & 133 & $70.7 \%$ \\
Reasonable & 55 & $29.3 \%$ \\
Unreasonable & & $61.2 \%$ \\
Occupation & 115 & $10.6 \%$ \\
Clerical/administrative/secretarial & 20 & $8.5 \%$ \\
Professional/technical positions & 16 & $6.9 \%$ \\
Government official/military & 13 & $6.9 \%$ \\
Executive/managerial positions & 13 & $5.9 \%$ \\
Self-employed & 11 & $100.0 \%$ \\
Teacher/instructor/professor & 188 & \\
Subtotal & & \\
\hline
\end{tabular}

To identify whether a single factor does account for the majority of the total variance of all the measurements, common method variance (CMV) was tested. Tehseen et al. [45] suggested Harman's single-factor test and controlling for the effects of an unmeasured latent methods factor by Podsakoff et al. [46] for CMV test. For Harman's single-factor test, an exploratory factor analysis (estimates factors which influence responses on observed variables in the data) employed the unrotated factor to account for the variance in the variables. Nine factors with an eigenvalue greater than one were identified and that the largest factor accounted for $36.404 \%$ of the total variance, less than $50 \%$ of the total variance is acceptable as per Harman's single factor test. For controlling for the effects of an unmeasured latent methods factor, we added a single common latent factor on measurement model to connect it to all observed variables in the measurement model of the study [46]. As shown in Table 4, the results indicated that the original measurement was similar to that of the extended model with an inclusion of the common latent factor. It means that common method bias would not be of concern [47].

Table 5 provides the square roots of average variance extracted (AVE) of latent variables, while the off-diagonal elements are correlations between latent variables. Campbell and Fiske [48] suggested that the construct validity is tested by discriminant and convergent validity. For discriminant validity, the square root of the AVE of any latent variable should be greater than the correlation between this particular latent variable and other latent variables [49]. For convergent validity of the measurement model, Fornell and Larcker [50] recommended that AVE measures the level of variance captured by a construct versus the level due to measurement error, values above .7 are considered very good, and the level of .5 is acceptable. The acceptable value of critical ratio $(\mathrm{CR})$ is .7 and above.

Statistics shown in Table 5 satisfied this requirement, leading to discriminant validity. As the values of AVE and CR of reputation, searching information, communication, 
Table 3 Results of reliability, CFA, and PCA

\begin{tabular}{|c|c|c|c|c|c|c|c|c|}
\hline \multirow[t]{2}{*}{ Factors } & \multirow[t]{2}{*}{ Constructs } & \multirow[t]{2}{*}{ Variables } & \multicolumn{2}{|l|}{ CFA } & \multicolumn{3}{|l|}{ PCA } & \multirow{2}{*}{$\begin{array}{l}\text { Cronbach's } \\
\text { alphas }\end{array}$} \\
\hline & & & $\begin{array}{l}\text { Standardized } \\
\text { loading }\end{array}$ & $t$ value & $\begin{array}{l}\text { Eigen } \\
\text { value }\end{array}$ & $\begin{array}{l}\text { Percent of } \\
\text { variance } \\
\text { explained }\end{array}$ & $\begin{array}{l}\text { Factor } \\
\text { loadings }\end{array}$ & \\
\hline \multirow{12}{*}{$\begin{array}{l}\text { Prior } \\
\text { experience (PREP) }\end{array}$} & \multirow[t]{3}{*}{ Reputation } & RE1 & .747 & 10.189 & \multirow[t]{3}{*}{1.061} & \multirow[t]{3}{*}{8.844} & .877 & \multirow[t]{3}{*}{.833} \\
\hline & & RE2 & .875 & 11.747 & & & .896 & \\
\hline & & RE3 & .770 & - & & & .826 & \\
\hline & \multirow{5}{*}{$\begin{array}{l}\text { Searching } \\
\text { information }\end{array}$} & SI1 & .762 & 9.239 & \multirow[t]{5}{*}{5.107} & \multirow[t]{5}{*}{42.557} & .858 & \multirow[t]{5}{*}{.892} \\
\hline & & $\mathrm{SI} 2$ & .911 & 10.656 & & & .841 & \\
\hline & & $\mathrm{SI} 3$ & .899 & 10.554 & & & .807 & \\
\hline & & $\mathrm{S} 14$ & .734 & 8.953 & & & .744 & \\
\hline & & SI5 & .657 & - & & & .644 & \\
\hline & \multirow[t]{4}{*}{ Communication } & $\mathrm{CO} 1$ & .515 & 6.765 & \multirow[t]{4}{*}{2.341} & \multirow[t]{4}{*}{19.509} & .567 & \multirow[t]{4}{*}{.811} \\
\hline & & $\mathrm{CO} 2$ & .847 & 11.650 & & & .766 & \\
\hline & & $\mathrm{CO} 3$ & .820 & 11.021 & & & .826 & \\
\hline & & $\mathrm{CO} 4$ & .751 & - & & & .823 & \\
\hline \multirow{12}{*}{$\begin{array}{l}\text { Current } \\
\text { experience (CUEP) }\end{array}$} & \multirow[t]{4}{*}{ Costs } & $\mathrm{CT} 1$ & .902 & 10.588 & \multirow[t]{4}{*}{5.495} & \multirow[t]{4}{*}{45.794} & .831 & \multirow[t]{4}{*}{.878} \\
\hline & & $\mathrm{CT} 2$ & .773 & 9.373 & & & .805 & \\
\hline & & СТ3 & .883 & 10.432 & & & .850 & \\
\hline & & $\mathrm{CT} 4$ & .664 & - & & & .756 & \\
\hline & \multirow[t]{5}{*}{ Care quality } & CQ1 & .695 & 9.930 & \multirow[t]{5}{*}{1.988} & \multirow[t]{5}{*}{16.563} & .854 & .895 \\
\hline & & CQ2 & .807 & 11.961 & & & .874 & \\
\hline & & CQ3 & .810 & 12.044 & & & .706 & \\
\hline & & CQ4 & .818 & 12.190 & & & .764 & \\
\hline & & CQ5 & .787 & - & & & .566 & \\
\hline & Supporting system & SU1 & .685 & 7.233 & 1.136 & 9.468 & .804 & .736 \\
\hline & ar & SU2 & .756 & 6.988 & & & .839 & \\
\hline & & SU3 & .653 & - & & & .780 & \\
\hline Post-experience & Relationship building & RB1 & .838 & 18.872 & 3.823 & 38.233 & .870 & .945 \\
\hline & & RB2 & .892 & 23.037 & & & .916 & \\
\hline & & RB3 & .926 & 26.825 & & & .936 & \\
\hline & & RB4 & .966 & - & & & .957 & \\
\hline & Recommendation & $\mathrm{RC1}$ & .843 & 7.369 & 1.981 & 20.673 & .883 & .767 \\
\hline & & $\mathrm{RC2}$ & .798 & 7.336 & & & .855 & \\
\hline & & $\mathrm{RC} 3$ & .571 & - & & & .745 & \\
\hline & Feedback & FB1 & .869 & 11.859 & 2.067 & 19.805 & .878 & .855 \\
\hline & & FB2 & .818 & 11.224 & & & .897 & \\
\hline & & FB3 & .760 & - & & & .844 & \\
\hline
\end{tabular}

Table 4 Results of fit indices for CFA

\begin{tabular}{lllllllll}
\hline Model & $X^{2}$ & d.f & $X^{2 / d}$.f & GFI & CFI & TLI & RMSEA & RMR \\
\hline Measurement model & 789.920 & 490 & 1.675 & .865 & .933 & .924 & .057 & .047 \\
Add a single common latent factor & 784.340 & 489 & 1.604 & .867 & .934 & .925 & .057 & .050 \\
Recommended values & & & & $>.9$ & $>.9$ & $>.9$ & $<.08$ & $<.05$ \\
\hline
\end{tabular}

GFI Goodness of Fit Index, CFI Comparative Fit Index, RMSEA root mean square error of approximation, RMR root mean square residual, $T L I$ Tucker Lewis Index 
Table 5 Correlation matrix and average variance extracted (AVE)

\begin{tabular}{|c|c|c|c|c|c|c|c|c|c|c|c|}
\hline Variables & RE & $\mathrm{SI}$ & $\mathrm{CO}$ & $C T$ & CQ & SU & RB & $\mathrm{RC}$ & $F B$ & Mean & SD \\
\hline $\mathrm{RE}$ & .883 & & & & & & & & & 3.492 & .815 \\
\hline SI & $.149^{*}$ & .853 & & & & & & & & 3.772 & .804 \\
\hline $\mathrm{CO}$ & $.135^{*}$ & $.628^{* *}$ & .802 & & & & & & & 3.900 & .743 \\
\hline $\mathrm{CT}$ & .070 & $.717^{* *}$ & $.628^{* *}$ & .891 & & & & & & 3.755 & .810 \\
\hline$C Q$ & $.181^{*}$ & $.732^{* *}$ & $.531^{* *}$ & $.687^{* *}$ & .816 & & & & & 3.572 & .823 \\
\hline SU & .026 & $.178^{*}$ & .028 & .041 & .098 & .816 & & & & 4.189 & .723 \\
\hline $\mathrm{RB}$ & $.186^{*}$ & $.788^{* *}$ & $.599 * *$ & $.692^{* *}$ & $.785^{* *}$ & .039 & .917 & & & 3.792 & .986 \\
\hline $\mathrm{RC}$ & $.198^{*}$ & .117 & .014 & .115 & .115 & $.469^{* *}$ & .039 & .843 & & 3.952 & .889 \\
\hline FB & $.681^{* *}$ & $.181^{*}$ & .036 & .066 & $.190^{* *}$ & .098 & $.260^{* *}$ & .023 & .883 & 3.620 & .889 \\
\hline$C R$ & .914 & .929 & .857 & .938 & .909 & .856 & .955 & .878 & .913 & & \\
\hline AVE & .780 & .727 & .644 & .793 & .666 & .666 & .840 & .711 & .779 & & \\
\hline
\end{tabular}

$\mathrm{CR}$ (critical ratio) $=\Sigma$ (factor loading $\left.{ }^{2}\right) /\left(\Sigma\right.$ (factor loading $\left.{ }^{2}\right)+\Sigma$ (error))

AVE $=\Sigma$ (factor loading $)^{2} /(\Sigma \text { (factor loading })^{2}+\Sigma$ (error))

${ }^{*} p<.05,{ }^{* *} p<.01$

costs, care quality, supporting system and/or information, relationship building, recommendation, and feedback were all greater than .6 and .8 , respectively, thus convergent validity met the threshold. Statistics shown in Table 5 therefore satisfied this requirement, lending evidence to construct validity as discriminant and convergent validity.

\section{Results}

This section presents the results of hypotheses testing, including the standardized coefficient of each path in the model. As a result of the goodness of fit test, compared to the recommended values, in this model the values of GFI (.857), CFI (.929), RMSEA (.058), RMR (.068), TLI (.920), and $\chi^{2} /$ d.f (1.639) were good for fit. In our model, the majority of fit indices showed good acceptance measures and GFI (.857) and RMR (.068) were below the required threshold.

Table 6 presents the results of the significance test for the proposed research model as well as the summary of the hypotheses test. For H1-1, H1-2, and H1-3 tests, patients' experience of their decision-making process before care, the standardized path coefficient between reputation and costs related with medical tourism (H1-1), care quality (H1-2), and supporting system and/or information (H1-3) were .030, .112, and .094, respectively. H1-2 was statistically significant at the .05 level, while H1-1 and H1-3 were not significant. Thus, H1-2 $(\beta=.112)$ was supported, while H1-1 $(\beta=.030)$ and H1-3 $(\beta=.094)$ were not supported.

With a well-known hospital for medical tourism, patients seek to ensure a positive experience with quality care by engaging in activities before care to ensure their satisfaction [19]. Thus, before making a final medical tourism decision, patients research the reputation of a particular hospital in advance, ensure that the hospital's communication enables them to achieve what they desire, and locate information through various media. Among the pre-care activities for medical tourism examined in the study, the hospital's reputation was shown to have a positive impact on the quality of care $[35,36]$, but not on the costs related with medical tourism or on the supporting system and/or information within a hospital. 
Table 6 Results of significance test for paths of the model

\begin{tabular}{|c|c|c|c|c|c|c|c|}
\hline Path & & Path coefficient & S.E. & $t$ value & $p$ value & Hypothesis test & \\
\hline Reputation $\rightarrow$ & Costs & .030 & .065 & .518 & .604 & $\begin{array}{l}\text { Not supported } \\
\mathrm{H} 1-1\end{array}$ & \multirow{9}{*}{$\begin{array}{l}\text { H1: Patients' } \\
\text { experience } \\
\text { on their } \\
\text { current } \\
\text { experience }\end{array}$} \\
\hline Reputation $\rightarrow$ & Care quality & .112 & .080 & 2.176 & $.030^{*}$ & $\begin{array}{l}\text { Supported } \\
\mathrm{H} 1-2\end{array}$ & \\
\hline Reputation $\rightarrow$ & $\begin{array}{l}\text { Supporting } \\
\text { system and/or } \\
\text { information }\end{array}$ & .094 & .110 & .977 & .329 & $\begin{array}{l}\text { Not supported } \\
\text { H1-3 }\end{array}$ & \\
\hline $\begin{array}{l}\text { Searching } \\
\text { information } \rightarrow\end{array}$ & Costs & .519 & .107 & 4.849 & $.000^{* * *}$ & $\begin{array}{l}\text { Supported } \\
\mathrm{H} 1-4\end{array}$ & \\
\hline $\begin{array}{l}\text { Searching } \\
\text { information } \rightarrow\end{array}$ & Care quality & .796 & .151 & 7.188 & $.000^{* * *}$ & $\begin{array}{l}\text { Supported } \\
\mathrm{H} 1-5\end{array}$ & \\
\hline $\begin{array}{l}\text { Searching } \\
\text { information } \rightarrow\end{array}$ & $\begin{array}{l}\text { Supporting } \\
\text { system and/or } \\
\text { information }\end{array}$ & .297 & .147 & 2.035 & $.042^{*}$ & $\begin{array}{l}\text { Supported } \\
\text { H1-6 }\end{array}$ & \\
\hline Communication $\rightarrow$ & Costs & .377 & .080 & 3.998 & $.000^{* * *}$ & $\begin{array}{l}\text { Supported } \\
\mathrm{H}-\mathrm{T}\end{array}$ & \\
\hline Communication $\rightarrow$ & Care quality & .108 & .089 & 1.418 & .156 & $\begin{array}{l}\text { Not supported } \\
\mathrm{H} 1-8\end{array}$ & \\
\hline Communication $\rightarrow$ & $\begin{array}{l}\text { Supporting } \\
\text { system and/or } \\
\text { information }\end{array}$ & .259 & .124 & 1.794 & .073 & $\begin{array}{l}\text { Not supported } \\
\text { H1-9 }\end{array}$ & \\
\hline Costs $\rightarrow$ & $\begin{array}{l}\text { Relationship } \\
\text { building }\end{array}$ & .147 & .117 & 2.153 & $.031^{*}$ & $\begin{array}{l}\text { Supported } \\
\mathrm{H} 2-1\end{array}$ & \multirow{9}{*}{$\begin{array}{l}\text { H2: Patients' } \\
\text { current } \\
\text { experience } \\
\text { on post- } \\
\text { experience }\end{array}$} \\
\hline Costs $\rightarrow$ & Recommendation & .423 & .167 & 6.961 & $.000^{* * *}$ & $\begin{array}{l}\text { Supported } \\
\mathrm{H} 2-2\end{array}$ & \\
\hline Costs $\rightarrow$ & Feedback & .372 & .152 & 3.327 & $.000^{* * *}$ & $\begin{array}{l}\text { Supported } \\
\mathrm{H} 2-3\end{array}$ & \\
\hline Care quality $\rightarrow$ & $\begin{array}{l}\text { Relationship } \\
\text { building }\end{array}$ & .800 & .099 & 10.113 & $.000^{* * *}$ & $\begin{array}{l}\text { Supported } \\
\mathrm{H} 2-4\end{array}$ & \\
\hline Care quality $\rightarrow$ & Recommendation & .732 & .108 & 6.750 & $.000^{* * *}$ & $\begin{array}{l}\text { Supported } \\
\mathrm{H} 2-5\end{array}$ & \\
\hline Care quality $\rightarrow$ & Feedback & .545 & .114 & 4.727 & $.000^{* * *}$ & $\begin{array}{l}\text { Supported } \\
\mathrm{H} 2-6\end{array}$ & \\
\hline $\begin{array}{l}\text { Supporting system } \\
\text { and/or information } \rightarrow\end{array}$ & $\begin{array}{l}\text { Relationship } \\
\text { building }\end{array}$ & .589 & .130 & 4.826 & $.000^{* * *}$ & $\begin{array}{l}\text { Supported } \\
\mathrm{H} 2-7\end{array}$ & \\
\hline $\begin{array}{l}\text { Supporting system } \\
\text { and/or information } \rightarrow\end{array}$ & Recommendation & .165 & .102 & 2.158 & $.031^{*}$ & $\begin{array}{l}\text { Supported } \\
\mathrm{H} 2-8\end{array}$ & \\
\hline $\begin{array}{l}\text { Supporting system } \\
\text { and/or information } \rightarrow\end{array}$ & Feedback & .036 & .075 & .809 & .419 & $\begin{array}{l}\text { Not supported } \\
\text { H2-9 }\end{array}$ & \\
\hline
\end{tabular}

For H1-4, H1-5, and H1-6 test, the standardized path coefficients between searching information on medical tourism and costs related to medical tourism (H1-4), care quality (H1-5), and supporting system and/or information (H1-6) were $.519, .796$, and .297 , respectively, and statistically significant at the .05 level, supporting H1-4, H1-5, and H1-6.

The results of this study supported previous studies $[6,10,25]$, which found that searching medical tourism has shown a positive impact on costs related with medical tourism, care quality, and supporting system and/or information. This means that researching for information in advance leads to a positive experience while visiting the hospital abroad. New digital devices provide opportunities for searching for accurate information through easy access to technology systems [51, 52]. 
For H1-7 test, the standardized path coefficient between communication about medical tourism and costs related with medical tourism (H1-7) was .377 and statistically significant at the .001 level, supporting H1-7. For H1-8 and H1-9, the standardized path coefficient between care quality (H1-8) and supporting system and/or information (H1-9) were .108 and .259, respectively, and not statistically significant at the .05 level. The result of H1-7 test was supported, while H1-8 and H1-9 were not supported. From these results, the following can be summarized.

No matter how well-coordinated decisions between a patient and a provider are, what patients expect based on prior experiences does not have a positive impact on care experiences. Some patients did not expect that high-quality care and a good supporting system and information would be provided in advance of the care. When medical tourists have good communication with a potential hospital provider, they positively weigh that communication in making medical tourism decision [53]. Thus, hospitals should honor the medical costs quoted and provide the quality of care and information that were promised in communications, both before and during care.

For H2-1, H2-2 and H2-3 tests, patients' current experience during their trip in Korea, the standardized path coefficient between cost related to medical tourism and relationship building with the hospital (H2-1), recommendation for medical tourism (H2-2), and feedback for the hospital (H2-3) were .147, .423, and .372, respectively, and statistically significant at the .05 level. Thus, H2-1, H2-2, and H2-3 were supported.

For H2-4, H2-5, and H2-6, the standardized path coefficients between care quality and relationship building with the hospital ( $\mathrm{H} 2-4)$, recommendation for medical tourism (H2-5), and feedback for the hospital (H2-6) were .800, .732, and .545, respectively, and statistically significant at the .001 level. Thus, H2-4, H2-5, and H2-6 were supported.

For H2-7 and H2-8 tests, the standardized path coefficient between supporting system and/or information to patients and relationship building with the hospital (H2-7) and recommendation for medical tourism (H2-8) were .589 and .165 respectively, and statistically significant at the .05 level. Thus, $\mathrm{H} 2-7$ and $\mathrm{H} 2-8$ were supported. For H2-9, the standardized path coefficient between supporting system and/or information to patients and feedback for the hospital (H2-9) was .036, and not statistically significant at the .05 level; thus, H2-9 was not supported.

The results of the study are similar to those of previous studies [36, 54]. Costs related with medical tourism had a positive impact on the relationship building with the hospital, recommendation for medical tourism, and feedback for the hospital. Thus, costs associated with medical tourism are a key factor that supports a thriving medical tourism industry.

Heung et al. [55] suggested that key players in medical tourism as hospitals, medical travel agencies, hotels, and the medical tourists themselves. As with previous studies [36, 54], the importance of care quality must be acknowledged by service providers because most medical tourists' expectations exceeded their perceptions of the quality of care provided. Therefore, healthcare facilities with medical tourism should be provided high standards of care quality and be permitted to facilitate cross national travel to improve healthcare services.

Based on the result of this study, medical travel facilitators should consider providing supporting systems and/or information to patients as a one-stop service offering integrated knowledge of medical care services and travel [56]. Hospital management could actively focus on achieving better care outcomes if supporting systems and/or information were provided by medical travel facilitators in advance. 


\section{Discussion and conclusions}

Medical tourism industry has drawn attention from international patients, travel agencies, governments, and the international accreditation sector $[1,4,5]$. Medical tourism can be arranged by the patients themselves by researching and booking on the internet, as well as by medical travel agencies [24, 29]. Therefore, medical tourists have information on the best and most well-known healthcare providers and travel arrangements before embarking on medical tourism (pre-experience), and then the medical tourism experience (current experience) affects whether the tourist will recommend the medical provider to other potential customers (post-experience). Thus, this paper advances the idea that all three stages of a patient's experience affect the medical tourism industry.

In this empirical study, we collected data to examine pre-experiences (e.g., reputation, searching information, and communication), current experiences (e.g., cost, care quality, and supporting system and/or information), and post-experiences (e.g., relationship building, recommendation, and feedback) in the medical tourism industry. The results of this study provide new insights about how key players (e.g., hospitals, medical travel agencies, hotels, and the medical tourists themselves) in medical tourism can effectively help managers identify medical tourists' needs based on medical tourists' decision-making process of pre, current, and post experience of medical tourism. In addition, the study sheds light on the perception of medical tourists on care quality and costs, as well as their future intention to obtain healthcare in the same hospital or country. Patient experience based on their interaction with medical staff and/or coordinators should be given as much importance as accuracy of diagnosis, treatment, and procedures.

The most important service attributes, which are highly attractive to international patients, will help medical travel agencies improve the information provided and develop innovative ideas among key players in medical tourism. As a variety of information retrieval functions grow and digital devices spread [52], medical tourism will gain a competitive edge by providing medical tourism information. Consumers will also have more opportunities to access information using comparative searches through different media.

Academically and practically, this paper provides several implications. First, developing and expanding a well-developed medical travel procedure based on patients' experiences is a prerequisite for successful medical tourism. Such decision-making process could be measured by integrating three types of customer experience to enhance customer satisfaction. Because many hospitals and travel agencies are striving to develop new protocols using advanced technologies, the proposed model should be easy to access and the reservation process should be simple. For example, a one-stop service system can help with travel arrangements, arrange airport pick up and local transportation, hotel recommendations, ancillary services at the hospital, scheduling tours to selected destinations, coordinating with insurance companies, and assisting with other paper work. To build an effective medical travel process for patients, healthcare facilities and travel facilitators must fulfill their promises. In other words, the promised services and costs should be provided without fail. For example, policymakers should ensure that the standard model of medical tourism include internationally accepted standardized care processes and insurance. The qualification criteria for medical tourism agents/brokers should be developed and enforced globally. Since customers from various countries visit a hospital, to overcome barriers to global medical tourism, the use of standardized communication devices should be available for customer convenience. 
This study has several limitations that should be considered when interpreting its findings, and future studies should also consider these limitations. First, the study assumed that hospitals visited by medical tourists have the same medical environments. Second, to collect data, we did not consider personal experiences and preferences for researching information. Third, data was collected from medical tourists in Korean hospitals located in Busan, South Korea, without considering the number of beds in the hospitals. Thus, the generalizability of this study's results may be limited. There are several potential future research opportunities considering these limitations. For example, as there are many different hospital sizes, a comparative study of small and large hospitals in terms of care quality and costs might yield interesting results. In addition, there are many different data characteristics based on the type of patients, disease conditions, and demographic characteristics (e.g., personal experience researching information with different media used, personal income, gender, etc.) that could be studied.

Acknowledgements

This research was supported by Busan Women's College in 2018.

\title{
Availability of data and materials
}

Data will not be shared, and give the reason.

\section{Authors' contributions}

All authors contributed to the developing research model, data collection, and writing of the manuscript. All authors read and approved the final manuscript.

\section{Competing interests}

The authors declare that they have no competing interests.

\section{Publisher's Note}

Springer Nature remains neutral with regard to jurisdictional claims in published maps and institutional affiliations.

\author{
Author details \\ ${ }^{1}$ Busan Women's college, Busan, South Korea. ${ }^{2}$ College of Business Administration, Inha University, Incheon, South \\ Korea. ${ }^{3}$ Department of Medical Information, Daejeon Institute of Science and Technology, Daejeon, South Korea.
}

Received: 4 July 2018 Accepted: 28 August 2018

Published online: 12 September 2018

\section{References}

1. Lajevardi M (2016) A comprehensive perspective on medical tourism context and create a conceptual framework. J Tourism Hospitality 5(5):1-12

2. de la Hoz-Correa A, Muñoz-Leiva F, Bakucz M (2018) Past themes and future trends in medical tourism research: a coword analysis. Tour Manag 65:200-211

3. Ngamvichaikit A, Beise-Zee R (2014) Communication needs of medical tourists: an exploratory study in Thailand. Int J Pharm Healthc Mark 8(1):98-117

4. Allied Market Research (AMR) (2018) Medical tourism market expected to reach $\$ 165,345$ million, by 2023. https://www. alliedmarketresearch.com/press-release/medical-tourism-market.html.

5. Orbis Research (2017) Medical tourism market shaped by innovation, shifting competitive landscape, forecast to 2022. https://www.reuters.com/brandfeatures/venture-capital/article?id=17353

6. Altin M, Singal M, Kara D (2011) Consumer decision components for medical tourism: a stakeholder approach. The 16th Graduate Student Research Conference in Hospitality and Tourism, University of Massachusetts, pp 1-11

7. Meyer C, Schwager A (2007) Understanding customer experience. Harv Bus Rev 85(2):116-126

8. De Keyser A, Lemon K, Keiningham T, Klaus P (2015) A framework for understanding and managing the customer experience. MSI working paper no. 15-121. Marketing Science Institute, Cambridge

9. Lee S, Lee D, Olson D (2013) Health-care quality management using the MBHCP excellence model. Total Qual Manage Bus Excell 24(1-2):119-137

10. Voorheesa C, Fombelleb P, Gregoirec Y, Boned S, Gustafssone A, Sousaf R, Walkowiakg T (2017) Service encounters, experiences and the customer journey: defining the field and a call to expand our lens. J Bus Res 79:269-280

11. Verhoef $P$, Lemon K, Parasuraman A, Roggeveen A, Schlesinger L, Tsiros M (2009) Customer experience: determinants, dynamics and management strategies. J Retail 85(1):31-41

12. Lee D (2017) A model for designing healthcare service based on the patient experience. Int J Healthc Manage (on-line) http://www.tandfonline.com/doi/full/10.1080/20479700.2017.1359956

13. Wolf J, Niederhauser V, Marshburn D, LaVela S (2014) Defining patient experience. Patient Exp J 1(1):7-19 
14. Nugraha A, Hamin H, Elliott G (2016) Tourism destination decisions: the impact of risk aversion and prior experience. Asia Pac J Tourism Res 21(12):1274-1284

15. Ofir C, Simonson I (2007) The effect of stating expectations on customer satisfaction and shopping experience. J Mark Res 44(1):164-174

16. Medical Tourism Association: http://www.medicaltourismassociation.com/en/medical-tourism-faq-s.html. Accessed 10 May 2018.

17. Wongkit M, McKercher B (2013) Toward a typology of medical tourists: a case study of Thailand. Tour Manag 38:4-12

18. Tourism Research and Marketing (TRAM) (2006) Medical tourism: a global analysis/ a report by tourism research and marketing. ATLAS, Arnhem

19. Lunt N, Smith R, Exworthy M, Green S, Horsfall D, Mannion R (2011) Medical tourism: treatments, market and health system implications: a scoping review. OECD Directorate for Employment, Labour and Social Affairs, p. 7

20. Tarcan E, Ates M, Sait VE (2015) An evaluation related to the effect of strategic facility management on choice of medical tourism destination. Marketing 46(2):124-131

21. Youngman I (2011) How medical tourism lost its way... and how it can get back on track. Int Med Trav J Retrieved from http://www.imtj.com/articles/how-industry-lost-its-way-and-how-it-can-get-back-track/

22. Ehrbeck T, Guevara C, Mango P (2008) Mapping the market for medical travel. McKinsey Quarterly:1-11. Retrieved from https://www.mckinseyquarterly.com/Mapping_the_market_for_travel_2134.

23. Crooks V, Kingsbury P, Snyder J, Johnston R (2010) What is known about the patient's experience of medical tourism? A scoping review. BMC Health Serv Res 10(266):1-12

24. Crouch G, Louviere J (2001) A review of choice modelling research in tourism, hospitality and leisure. Consum Psychol Tourism Hospitality Leis 2:67-86

25. Horowitz MD, Rosensweig JA, Jones CA (2007) Medical tourism: globalization of the healthcare marketplace. Medscape Gen Med 9(4):33-39

26. Crooks VA, Turner L, Snyder J, Johnston R, Kingsbury P (2011) Promoting medical tourism to India: messages, images, and the marketing of international patient travel. Soc Sci Med 72(5):726-732

27. Snyder J, Crooks VA, Adams K, Kingsbury P, Johnston R (2011) The patient's physician one-step removed: the evolving roles of medical tourism facilitators. J Med Ethics 37(9):530-534

28. Ormond M, Sothern M (2012) You, too, can be an international medical traveler: reading medical travel guidebooks. Health Place 18(5):935-941

29. Johnston R, Crooks V, Snyder J, Kingsbury P (2010) What is known about the effects of medical tourism in destination and departure countries? A scoping review. Int J Equity Health 9(24):1-13

30. Trusko B, Pexton C, Harrington H, Gupta P (2007) Improving healthcare quality and cost with six sigma. FT Press, Upper Saddle River

31. Merlino J, Raman A (2013) Health care's service fanatics: how the Cleveland clinic leaped to the top of the patientsatisfaction surveys. Harv Bus Rev 91(5):108-116

32. Sridhar S, Srinivasan R (2012) Social influence effects in online product ratings. J Mark 76(5):70-88

33. Gavett $G$ (2015) How self-service kiosks are changing customer behavior. Harv Bus Rev 93(3):1-6

34. Larivière B, Bowen D, Andreassen T, Kunz W, Sirianni N, Voss C, Wünderlich N, Keyser A (2017) Service encounter 2.0: an investigation into the roles of technology, employees and customers. J Bus Res 79:238-246

35. Ferguson RJ, Paulin M, Leiriao E (2007) Loyalty and positive word-of-mouth: patients and hospital personnel as advocates of a customer-centric health care organization. Health Mark Q 23(3):59-77

36. Cheng SH, Yang MC, Chiang TL (2003) Patient satisfaction with and recommendation of a hospital: effects of interpersonal and technical aspects of hospital care. Int J Qual Healthc 15(4):345-355

37. Lemon $K$, Verhoef $P$ (2016) Understanding customer experience throughout the customer journey. J Mark 80(6):69-96

38. Lee D, Kim K (2017) Assessing healthcare service quality: a comparative study of patient treatment types. Int I Qual Innov 3(1):1-15 https://doi.org/10.1186/s40887-016-0010-5

39. Polluste K, Kalda R, Lember M (2000) Primary health care system in transition: the patient's experience. Int J Qual Health Care 12(6):503-509

40. Jeong J (2014) Healthcare service quality and its effects on perceived service value and consumer satisfaction. Doctoral Dissertation. University of Ga Chon, Korea

41. Harkness J (2011) Guidelines for best practice in cross-cultural surveys. Survey Research Center, University of Michigan Institute for Social Research, Ann Arbor

42. Nunnally J (1978) Psychometric theory, 2nd edn. McGraw Hill, NY

43. Brown T (2006) Confirmatory factor analysis for applied research. The Guilford Press, NY

44. Deepen J (2009) Logistics outsourcing relationships. Springer: Physica Verlag, Heidelberg

45. Tehseen S, Ramayah T, Sajilan S (2017) Testing and controlling for common method variance: a review of available methods. J Manage Sci 4(2):142-168

46. Podsakoff P, MacKenzie S, Lee J, Podsakoff N (2003) Common method biases in behavioral research: a critical review of the literature and recommended remedies. J Appl Psychol 88(5):879-903

47. Satorra A, Bentler P (2001) A scaled difference chi-square test statistic for moment structure analysis. Psychometrika 66:507-514

48. Campbell D, Fiske D (1959) Convergent and discriminant validation by the multitrait-multimethod matrix. Psychol Bull 56(2):81-105

49. Barclay D, Thompson R, Higgins C (1995) The partial least squares (PLS) approach to causal modeling: personal computer adoption and use as an illustration. Technol Stud 2(2):285-309

50. Fornell C, Larcker D (1981) Evaluating structural equation models with unobservable variables and measurement error. J Mark Res 18(1):39-50

51. Al-Maaitah H (2016) An investigation of the acquisition and experience of medical tourism: the case of Jordan. Doctor of Dissertation. Hashemite University, Zarqa, Jordan

52. Lee S (2018) Innovation: from small "i" to large "I". Int J Qual Innov 4(2):1-3 https://doi.org/10.1186/s40887-018-0022-4

53. Li R, Suh A (2015) Factors influencing information credibility on social media platforms: evidence from Facebook pages. Procedia Comput Sci 72:314-328

54. Boulding W, Glickman SW, Manary MP, Schulman KA, Staelin R (2011) Relationship between patient satisfaction with inpatient care and hospital readmission within 30 days. Am J Manage Care 17(1):41-48 
55. Heung V, Kucukusta D, Song H (2010) A conceptual model of medical tourism: implications for future research. J Travel Tour Mark 27(3):236-251

56. Jagyasi P (2010) Medical tourism impact it's more than obvious. Retrieved from: http://www.medicaltourismmag.com/ medical-tourism-impact-itaes-more-than-obvious/

57. Saiprasert W (2011) An examination of the medical tourists motivational behavior and perception: a structural model. Doctoral Dissertation. Oklahoma State University, USA

Submit your manuscript to a SpringerOpen ${ }^{\circ}$ journal and benefit from:

- Convenient online submission

- Rigorous peer review

- Open access: articles freely available online

High visibility within the field

Retaining the copyright to your article

Submit your next manuscript at $\boldsymbol{\nabla}$ springeropen.com 